\title{
The Origins of Yahwism from the Perspective of Deuteronomism
}

\section{Pakkala, Juha Kalevi}

de Gruyter

2017

Pakkala , J K 2017 , The Origins of Yahwism from the Perspective of Deuteronomism . in M Witte \& J van Oorschot (eds), The Origins of Yahwism . Beihefte zur Zeitschrift für die alttestamentliche Wissenschaft , no. 484 , de Gruyter , Berlin , pp. 267-281 . https://doi.org/10.1515/9783110448221

http://hdl.handle.net/10138/310386

https://doi.org/10.1515/9783110448221-012

unspecified

acceptedVersion

Downloaded from Helda, University of Helsinki institutional repository.

This is an electronic reprint of the original article.

This reprint may differ from the original in pagination and typographic detail.

Please cite the original version. 


\section{The Origins of Yahwism}

\section{from the Perspective of Deuteronomism}

\section{Introduction}

This paper seeks to sketch the origins and early development of Yahwism ${ }^{1}$ as it appears from the perspective of Deuteronomistic texts. ${ }^{2}$ They provide an excellent glimpse to the development of Yahwism from the sixth to fourth centuries BCE, when these texts were mainly written. This period was crucial for the eventual and later development of monotheistic conceptions that lie at the background of three world religions. Deuteronomistic literature may also be the most fruitful area for observing and understanding the reasons for the exceptional development that led Israel's religion to a trajectory away from the other religions of the Ancient Near East. Although the Deuteronomists were active from the sixth century BCE onwards, their sources also contain some information about the earlier development of Yahwism. ${ }^{3}$

The Hebrew Bible is not an unproblematic source for investigating the history of Israel's religion especially in the monarchic period. Most texts were written after the destruction of Jerusalem in 587 BCE, which meant the destruction of the main structures of the ancient Israelite society: the temple, monarchy, and other state institutions. This destruction necessitated and entailed a complete reorientation of Israel's religion, and this has to be taken into consideration when using the Hebrew Bible as a historical source. Consequently, there are considerable challenges when Israel's religion in the monarchic period is reconstructed on the basis of texts that were written later and largely represent a very different religion that had already adapted itself to the new situation without the temple

1 In this paper Yahwism refers to the worship and cult of YнwH.

2 Deuteronomism is here defined rather generally to include the Deuteronomic sections and redactions of Deuteronomy as well as the Deuteronomistic texts and redactions in the books from Deuteronomy to 2 Kings. It is necessary to acknowledge the uncertainties concerning Deuteronomism especially in the Book of Samuel but also in Joshua and Judges. See discussion in C. Edenburg and J. Pakkala (ed.), Is Samuel Among the Deuteronomists? Current Views on the Place of Samuel in a Deuteronomistic History (SBLAIL 16; Atlanta, GA 2013). Although not very specific, Deuteronomism is a usable concept for the purposes of the current paper.

3 Using other parts of the Hebrew Bible and beyond, the very early evidence for Yahwism will be discussed in much more detail in other papers of this volume. 
and the king. It seems probable that the Hebrew Bible only contains vestiges of the early and monarchic religion, for especially features that contradicted with later conceptions would have been left out or outright censored in the post587 BCE texts. Parts of the old mythology featuring the monarchic religion are best preserved in the Psalms and other poetic literature, as their liturgical and hymnic contexts as well as the poetic form may have conserved ancient features better than the context and form of prose.

Methodologically this paper is based on literary and redaction critical analysis of the source texts. Although these methods have their limitations, it has become evident that the preserved texts were written by many authors, editors, and redactors in different times and contexts. It is therefore necessary to distinguish between different authors if we use the text as a source to reconstruct the history and religion of ancient Israel. ${ }^{4}$ For the rise of Yahwism this approach is particularly fruitful, because it reveals crucial differences between Deuteronomistic literary layers, which implies the development of concepts during the time when these texts were produced. ${ }^{5}$

It should further be noted that the Deuteronomistic texts, as well as much of the rest of the Hebrew Bible, mainly deal with the state religion and the religion of the powerful. The Hebrew Bible was written by a group of people who probably represent only a small section of the society, the literate elite, who was close to the society's powerful. For example, the main source for the book of Kings was the royal annals, which recorded events from the perspective of the royal house. It is therefore probable that the Hebrew Bible provides only scanty evidence for the various forms of Yahwism practiced by the ordinary people on a local level. One also has to assume considerable local differences.

\section{Pre-Deuteronomistic Yahwism}

Although witnessed by the Deuteronomistic texts only in vestiges, it is necessary to give a brief overview of the development predating and leading to Deuteronomistic conceptions. Because sources are lacking or fragmentary, the very earliest Yahwism is controversial. Traditionally it has been assumed that YHwH did not

\footnotetext{
4 See discussion in R. Müller et al., Evidence of Editing. Growth and Change of Texts in the Hebrew Bible (SBLRBS 75; Atlanta 2013). Failure to distinguish between different authors and editors would mean that we can only use the final texts as a very general source and then acknowledge that texts from very different contexts and centuries are intermingled.

5 For literary and redaction critical analysis of the texts discussed in this paper, see J. Pakkala, Intolerant Monolatry in the Deuteronomistic History (PFES 76; Helsinki and Göttingen 1999).
} 
originate in Palestine but came from a region south of Judah perhaps at the end of the Bronze Age. There are some indications in support of this view. The giving of the law and the sojourn of the Israelites is strongly tied with the Sinai, an area outside of Israelite and Judean heartland, which begs for an explanation. Four short passages, often assumed to be early vestiges, point to the same geographical direction. These passages mention YHwh's coming from areas that can be located in the Sinai or Edom: Judg 5:4-5, 31 from Seir and Edom, Hab 3:3-4, 7 from Teman, Deut 33:2 from Seir and Paran, and Ps 68:8-9 from Sinai. It would be difficult to explain, why the national God of Israel and Judah had originated in an area of another nation, unless there was a strong tradition behind it.

There is also extra-biblical evidence to connect YнwH with the general area of Sinai and Edom. As many scholars have pointed out, some Late Bronze Age texts from Egypt link YHwH with Šasu, which have been assumed to be a people living in the approximate area south of Judah. ${ }^{6}$ Moreover, the inscriptions from Kuntillet 'Ajrud in the Sinai could also be seen as argument to connect YHWH with this region. In addition to its southern location, some of the texts (KAgr 9:6, 9, 10) mention Yнwн of Teman. ${ }^{7}$ Incidentally, Teman is also mentioned in Hab 3:3, where it is paralleled with Paran, which may be connected with Edom (Deut 33:2) or is otherwise in the general area. Taking all this evidence together, many scholars have assumed that YHwH's origins are somehow connected with the general area in Edom and Sinai. ${ }^{8}$

Nevertheless, recently some scholars have challenged the southern origins of YHwH. Henrik Pfeiffer in particular has shown the weaknesses of using the biblical fragments as well as the extra-biblical references. He argues that the four short passages are literarily interdependent, Judg 5 being the oldest but still of post-monarchic origin. ${ }^{9}$ If his analysis is correct, the passages are not a strong witness to the early origins of YHWH. Moreover, Reinhard Müller has provided

6 See S. Herrmann, "Der Alttestamentliche Gottesnahme” in Gesammelte Studien zur Geschichte und Theologie des Alten Testaments (TB 75; München 1966), 76-88.

7 According to Ernst A. Knauf, “Teman,” Das wissenschaftliche Bibellexikon im Internet (2009), (https://www.bibelwissenschaft.de/de/stichwort/33170/), Teman primarily means "south", and since YHWH of Judah or Jerusalem is not otherwise mentioned in the Kuntillet "Ajrud inscriptions, it is probable that Yнwн of Teman refers to YнwH of Judah, the southern kingdom. 8 With many others, thus K. van der Toorn, "Yahweh," $D D D^{2}$ (ed. K. van der Toorn; Leiden ${ }^{2} 1999$ ), 910-919, especially pp. 911-913, and most recently M. Leuenberger, "Jhwhs Herkunft aus dem Süden. Archäologische Befunde - biblische Überlieferungen - historische Korrelationen," ZAW 122 (2010), 1-19.

9 See Pfeiffer's contribution in this volume; he also provides good arguments to be more cautious with the use of the extra-biblical sources for the early origins of YHWH. 
an alternative solution to the southern origins and shown that YHwH's early characteristics, preserved as vestiges in some poetic texts of the Hebrew Bible, correspond with those of a typical Syrian-type weather god. ${ }^{10}$ This would make origins in the arid zones of Edom or Sinai unlikely.

In the end, the southern hypothesis remains a possibility, but for understanding Yнwн as a divinity it does not contain much substance. For the development of YHWH, his clear characteristics as a weather god are much more important. Certainly, one can speculate that YHWH, at least as the name of the divinity, came from outside Palestine, perhaps from the South. Having some similar characteristics with a local weather god, he would have retained an old name, but otherwise merged with an older Syro-Palestinian storm god. ${ }^{11}$ At any rate, it seems probable that YнwH, at least as the name of the deity, has an origin outside the conventional and known core-pantheons of Syria-Palestine. ${ }^{12}$

Regardless of his early origins, YнwH was the main divinity worshipped in the kingdoms of Israel and Judah during most of the monarchic period, but the $10^{\text {th }}$ and the first half of the $9^{\text {th }}$ century BCE are uncertain. While the early history of Judah-and thereby also the history of YHwH of Jerusalem-is poorly known and controversial, we are on a more solid ground with the kingdom of Israel. Historically it seems certain that Yнwн became the unquestioned dynastic and state God of Israel by mid $-9^{\text {th }}$ century BCE, during the time of Omri or Ahab. For example, the Mesha inscription, which can be dated to the second half of the $9^{\text {th }}$ century BCE, refers to YнWH as the divinity of the kingdom of Israel (line 18). Moreover, an inscription from Kuntillet 'Ajrud refers to the YнwH of Samaria (KAgr 9:8), which implies that Samaria had become a significant location of YHwH's cult already by beginning of the eight century BCE, when the inscription was written.

It seems probable that the house of Omri was a strong proponent of Yahwism. This is suggested by the mostly Yahwistic names of kings after King Ahab. Before Ahab's son Ahaziah none of the Israelite kings had a Yahwistic name, which implies a dramatic shift in the time of Omri and Ahab. There may even

10 R. Müller, Jahwe als Wettergott. Studien zur althebräischen Kultlyrik anhand ausgewählter Psalmen (BZAW 387; Berlin), 241-244.

11 If one follows this line, a possible candidate would be Baal. This could explain why Baal is largely missing as a theophoric element in personal names as well as in the inscriptions. Nevertheless, there is very little evidence for this hypothesis.

12 The Amarna correspondence does not contain any personal name with YHWH as a theophoric element, which suggests that Yнwн was either an insignificant local deity during the Late Bronze Age or that he came later from outside Palestine. 
be indirect textual evidence in 1 Kings 16:32 that Ahab built a temple for YHWH in Samaria. According to the Masoretic text, "Ahab erected an altar for Baal in the Baal's temple, which he had built in Samaria” (מיקם מזבח לבעל בית בעל אשר בנה

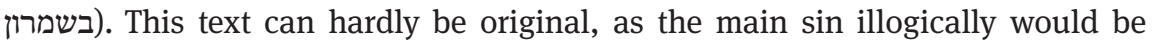
the erection of Baal's altar, while the building of the temple is mentioned merely as the place of the sin. It would be much more logical that the sin was the erection of Baal's altar in YHwH's temple. It is notable that the references to the temple differ considerably in the witnesses (for example, the LXX reads ćv olk $\omega \tau \tilde{\omega} \nu$

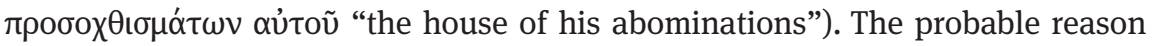
for the variant readings is that the original text contained an offensive or problematic reading that later scribes tried to avoid. A reference to the existence of YHwH's temple in Samaria would certainly have been a problematic reading causing many scribes to censor it. Consequently, the original text, which is not preserved in any witness, probably read "He (Ahab) erected an altar for Baal in the temple of Yнwh, which he had built in Samaria” (יקם מזבח לבעל בית יהוה אשר בנה בשמרון. ${ }^{13}$

The building of YHwH's temple in the new capital Samaria would have given a powerful boost to promote the state god of the new dynasty and its new capital. Considering the position of Samaria in the $9^{\text {th }}$ century BCE, it would seem logical that the rise and eventual success of YHwH is the result of his elevation to the status of state God of the house of Omri. YHwH's characteristics as a Syrian type weather god may derive from or be a result of this period, for in the mid $9^{\text {th }}$ century Israel was well connected with Syria and Lebanon. ${ }^{14}$ Ironically, two of the most derided Israelite kings, Omri and Ahab, may have been essential in promoting early Yahwism.

The pre-Deuteronomistic remains in the Deuteronomistic literature give an impression of a strongly YHWH -centered religion during the monarchic period. Certainly this picture is partly a result of censoring, but only partly. The theophoric elements in personal names imply that Yнwн was clearly the dominant deity who was not challenged after the $9^{\text {th }}$ century BCE. Asherah had a role as implied by the vestiges in the Hebrew Bible as well as by the inscriptions from Kuntillet 'Ajrud and Khirbet el-Qom - but this divinity seems to have been closely connected with YHwH's cult, probably as his consort. It is fair to assume that YHWH and El were originally separate divinities, but since most of the

13 For details, evidence, and arguments in favor of this hypothesis, see J. Pakkala, God's Word Omitted. Omissions in the Transmission of the Hebrew Bible (FRLANT 251; Göttingen 2013), 231234.

14 For example, according to the Kurkh stela, Israel under Ahab was part of a military alliance with Damascus and Hamath against Assyria. 
Hebrew Bible implicitly identifies them, it is probable that they had merged or were in the process of merging at least by end of the monarchic times. ${ }^{15}$

Baal's role has been subject of wide discussion, not the least because the Hebrew Bible criticizes the Israelites of worshipping this deity, but there is very little evidence that Baal had a significant position in Israel or Judah during the monarchic period. For example, Baal is met only seldom as a theophoric element of personal names on seals and inscriptions from the monarchic period. ${ }^{16}$ The El Amarna correspondence similarly contains only a few personal names with Baal as a theophoric element. This would seem to suggest that Baal never had a similar position in Palestine as he had in Lebanon and (parts of) Syria. He is mentioned in a Kuntillet 'Ajrud inscription (KAgr 9:7), but so far there is not much evidence to suggest that he was a major deity in Israel or Judah during the monarchic time. This is understandable, since YHWH and Baal had very similar characteristics that would hardly fit the same pantheon or be both needed by the same worshipper. ${ }^{17}$ In other words, YHwH's dominance explains why Baal is largely missing, at least in the monarchic period. Alternatively, YHWH and Baal could have been identified, but the evidence for this is meagre. There is some evidence for their worship in the same contexts-the original text of 2 Kings 10:23 ${ }^{18}$ and KAgr 9:7 $7^{19}$-but they are too uncertain and open to interpretation to build a solid case.

15 Thus many, for example, van der Toorn, "Yahweh" (see n. 8), 917.

16 See J. H. Tigay, You Shall Have No Other Gods. Israelite Religion in the Light of Hebrew Inscriptions (HSM 31; Atlanta 1986). In the material discussed by Tigay, Baal is met only six times, out of which five are in the Samaria ostraca. Although new personal names have been found on seals and inscriptions after his analysis, personal names with Baal as the theophoric element still form a small fraction of all names. Nevertheless, J. Day, Yahweh and the Gods and Goddesses of Canaan (JSOTS 265; Sheffield 2002), 226-228, has criticized Tigay's conclusions and suggested that the worship of other gods may have been more common. Day writes: "My overall conclusion is that Yahweh was very much the chief god in ancient Israel, and the other gods and goddesses would have been worshipped as part of his pantheon, but the frequency of their worship has been underestimated by Tigay."

17 That Yнwн was a Baal-Adad type weather god has been convincingly demonstrated by Müller, Jahwe als Wettergott (see n. 10), 241-244.

18 Second Kings 10:23 is a possible but quite uncertain source for a Baal-YHwH syncretism. The verse seems to imply that Baal and YнwH were worshipped in the same sanctuary. The original reference to a syncretistic cult has been censored in the Masoretic text by omitting the offensive section of the passage, but the Old Greek and Codex Vindobonensis, an Old Latin witness, have preserved the original reading. This position has been argued by J. T. Barrera, Jehú y Joás: Texto y composición literaria de 2 Reyes 9 - 11 (Institución San Jerónimo 17; Valencia 1984), 147-157, 222223. For discussion, see also Pakkala, God's Word Omitted (see n. 13), 234-237. 
All in all, it is probable that Israel's monarchic religion was essentially polytheistic in its conceptions, but with a tendency towards YHWH-monolatry at least in Judah by the $7^{\text {th }}$ century BCE. This provides the background for the later development towards the exclusive worship of YнwH that developed after the destruction of Jerusalem in 587 BCE. The reasons for the concentration on one divinity are unclear but they may be connected to the provincial and perhaps somewhat secluded location of Judah, its small size, and its relatively homogenous population. $^{20}$

Many scholars have assumed that there was a party or group of people, who demanded the exclusive worship of YHwH already during the monarchic times. ${ }^{21}$ The main evidence in support of a general attack on other gods before 587 вCE have been the religious reforms of Hezekiah and Josiah. ${ }^{22}$ Especially Josiah's reform has often been regarded as a historical event where new ideas in Israel's religion were initiated. ${ }^{23}$ The invention of Deuteronomy is often connected to the reform as well. However, it is very unlikely that any religious reforms in the sense intended by the authors of 2 Kings 18:4 and 23:1-24 took place. I have provided arguments for this position in a separate article, and will only refer to some arguments and considerations here. ${ }^{24}$

Rather than being historical events, it is more likely that the reform accounts are projections of later, post-monarchic BCE religious ideals into a monarchic context. This would explain the blatant contradiction between the reality, im-

19 Although the text is fragmentary and consists of a few lines only, El, YHwH and Baal seem to be mentioned in this hymn that is reminiscent of some theophanies of the Hebrew Bible.

20 Although there is very little information about the religion in Edom, Moab, and Ammon during the Iron Age, the scant evidence seems to suggest a concentration on the main god. It stands to reason that in areas with a heterogeneous population and wide international contacts the divine has the tendency to become more complex. It should be emphasized that our theories concerning this period are based on very little information, and thus a new significant find could considerably change the way we understand the monarchic religion of Israel.

21 Thus, among many others, M. Smith, Palestinian Parties and Politics that Shaped the Old Testament (New York 1971); B. Lang, "The Yahweh-Alone-Movement and the Making of Jewish Monotheism," in Monotheism and the Prophetic Minority (Sheffield 1983), 13-59; Day, Yahweh and the Gods (see n. 16), 228-229.

22 The criticism of other gods in some books of the prophets, especially in Hosea, has traditionally been used as an indicator that demands for the exclusive worship of YHWH were made already during the monarchic period.

23 For example, Day, Yahweh and the Gods (see n. 16), 230.

24 For discussion and arguments, see J. Pakkala, "Why the Cult Reforms in Judah Probably Did not Happen," - One God - One Cult - One Nation. Archaeological and Biblical Perspectives (Ed. R. Kratz and H. Spieckermann in collaboration with B. Corzilius and T. Pilger; BZAW 405; Berlin 2010), 201-235. 
plied in the reforms accounts, and the religious ideals of the reforms. It would be very unusual that during the monarchic times the Israelites were almost constantly at war with the demands of their own religion and that only some kings defended the accepted religion. In addition to a strange conception that a nation always fails the demands of its God, the reforms would be a structural peculiarity during monarchic times.

From a textual and source-critical perspective, the reforms stand on a thin basis. Hezekiah's reform is only mentioned in one verse (2 Kings 18:4), which many scholars have argued to be a late addition. Josiah's reform in 2 Kings 23, on the other hand, is one of the most edited and debated texts in the Hebrew Bible. The reforms are not mentioned in any other passage in the Hebrew Bible or in other contemporary literature. Consequently, the evidence for a systematic attack on other gods during the monarchic times is too scanty to assume that demands for exclusive worship of YHWH were made before the destruction of 587 BCE.

Instead of relying on biblical texts that have been heavily edited in post-587 BCE contexts, one needs to find more fundamental reasons for a development that took Israel's religion into a path that eventually separated it from other religions of the Ancient Near East. Since a major reorientation in Israel's religion took place at some point in the $8^{\text {th }}$ to $4^{\text {th }}$ centuries BCE, it is most logical that it took place as a result of the events in 587 BCE. The destruction of the temple, monarchy, and state - the sudden loss of the main institutions of the religion -would have necessarily caused a dramatic change in Israel's religion. ${ }^{25}$ For example, it is difficult to see that the temple cult in Jerusalem would not have been an essential part of any YHwH religion in monarchic Judah. With a possible image of YHWH and his ark, ${ }^{26}$ the temple was also the presence and house of the divinity, with which the royal ideology and mythology would have been connected in some way. It also stands to reason that the monarchic institution was closely tied with Yahwism. Consequently, it is difficult to see how the monarchic religion could have continued without a fundamental change after the destruction of the temple.

25 Considering the importance of the royal house in other known religions of the Ancient Near East, the end of the Davidic dynasty would have brought about a similar crisis as the loss of the temple.

26 It seems increasingly probable that there was an image of Yнwн in the temple. See, for example, the discussion by H. Niehr, "In Search of YHWH's Cult Statue in the First Temple," in The Image and the Book: Iconic Cults, Aniconism, and the Rise of Book Religion in Israel and the Ancient Near East (ed. K. van der Toorn; CBET 21; Leuven 1998), 73-95. 
This leads us to the evidence preserved in the Deuteronomistic literature that provides a more solid ground to see what happened next in Israel's religion. The pre-587 всE features of YHWH are mainly preserved as fragments, while much of the YнwH that the Hebrew Bible portrays was shaped by Deuteronomism.

\section{Deuteronomistic History Writer and Deuteronomy}

For the purposes of the current paper, the Deuteronomistic History writer ${ }^{27}$ and the Deuteronomic author of Deuteronomy largely imply a similar picture of YHWH. ${ }^{28}$ It is probable that both of these literary phases were written after the catastrophe of 587 всE. $^{29}$ In their portrayal Israel has only one God, YHwH, and the intimate relationship between YнwH and the people of Israel neither needs nor gives much space to other divinities, but there does not seem to be any explicit exclusion of other gods. Although one cannot completely rule out the possibility that positive references to other gods were later censored from these literary phases, this seems improbable. The YHwH of these texts functions as the sole divinity to whom Israel is responsible and in relation to whom Israel should live. Israel's history and future is only determined by YнwH, who judges on the basis of how Israel obeys and follows him. In other words, there is a silent and de facto exclusion of other divinities, but no explicit command to reject or to condemn other gods can be connected with these literary phases. The position of the history writer and the Deuteronomic authors towards the other gods can be characterized as tolerant but within a clearly monolatric framework, where YHWH is the unquestioned God of Israel.

27 This author is conventionally called DtrH, but there are considerable problems related to the original theory that the same author edited all books from Joshua to 2 Kings. Nevertheless, it is possible to distinguish a history writer, who represents Deuteronomistic conceptions, at least in the book of Kings, but the Deuteronomistic contribution in Samuel in particular, and perhaps also in Judges, is more controversial.

28 Many controversial and debated issues are connected to the relationship between Deuteronomy and the books from Joshua to 2 Kings, but they are not directly relevant to the aims of this paper.

29 The post-587 BCE dating of the Deuteronomistic editors has been widely accepted in continental European scholarship, whereas the dating of the so-called Urdeuteronomium and the Deuteronomic authors is more debated. For arguments in favor of post-monarchic origin of $U r$ deuteronomium, see J. Pakkala "The Date of the Earliest Edition of Deuteronomy," ZAW 121/3 (2009), 388-401. 
In comparison with the monolatric tendencies of the monarchic times, Israel's religion took small step further, as it is probable that the roles other divinities had had before 587 BCE are largely missing in the Deuteronomic/Deuteronomistic tradition that emerged after 587 BCE. The reason for Asherah's disappearance or abandonment may have been the destruction of her main symbol in the temple in 587 BCE. In other words, there may not have been any active rejection of her or an attack on her cult; she would have been left out of the history writer's presentation because with the destruction of her physical symbol and representation, her main cult in the temple would have lost its basis. This does not mean that Asherah would have been abandoned in all contexts, ${ }^{30}$ but since the history writer as well as the original authors of Deuteronomy were largely focused on the temple, its destruction would have mean the end of Asherah as an important divinity. Therefore, their conception of Yahwism did not need Asherah.

Although the temple had already been destroyed in 587 BCE, it remains the conceptual center of Yahwism. ${ }^{31}$ For the history writer and Deuteronomic authors the main concern was the sacrificial cult of Yнwн in many places; there may only be one place where the Israelites were allowed to sacrifice to Yнwн. At the background was probably the concern of many YHwHs, because each temple and sacrificial cult potentially nurtured a different form of Yahwism. Instead of seeking the background of centralization in Josiah's time, a situation after 587 BCE is more probable. Jerusalem had ceased to be the unquestioned center of Yahwism, which inevitably increased the importance of local forms of Yahwism. The prohibition to sacrifice locally may thus have been an attempt to control them.

Although the exact reasons for the appearance of centralization are unclear and debated, it was a significant step towards defining and regulating Yahwism. It started a long tradition that gradually prohibited features that should not be-

30 Many scholars assume that Asherah continued to be worshipped after 587 BCE. Thus, for example, S. Ackerman, Under Every Green Tree (HSM 46; Atlanta 1992), 5-99 and H. Niehr, "Religio-Historical Aspects of the 'Early Post-Exilic' Period," in The Crisis of Israelite Religion. Transformation of Religious Tradition in Exilic and Post-Exilic Times (ed. B. Becking and M.C.A. Korpel; OTS 42; Leiden 1999) 228-244, here 240. This is very probably the case outside the Deuteronomistic tradition.

31 The author of Kings in particular is very centered on and interested in the Temple. From the annals he took several texts that mention the Temple: its repairs in 2 Kgs 12:5-16; 22:4-7, its

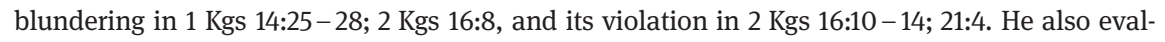
uated the kings on the basis of how they related towards the Temple. Kings who repaired or contributed to the Temple were regarded as good (e.g., Asa, Hezekiah, Jehoash and Josiah), but its violators were regarded as bad (e.g., Ahaz and Manasseh). 
long to Yahwism. The idea of excluding something from the legitimate cult is a prominent feature in early Deuteronomy and in the history writer's text, and this feature is further increased in later Deuteronomism. Moreover, the development towards oneness also begins in this phase, although it was still restricted to the oneness of the cult. The rise of these ideas were essential for the later development towards oneness of the entire divinity and the exclusion of other gods.

\section{Intolerant Monolatry in the Nomistic Texts}

One can see a clear change in attitude inside Deuteronomism. Whereas the history writer and the Deuteronomic author are largely silent about the other gods, this changes dramatically in the late Deuteronomistic texts, which for the purposes of this paper are called nomistic. ${ }^{32}$

The ideas of oneness and exclusivity were inherited from the history writer, but the nomists expanded them to include the other gods, while cult centralization recedes to the background. It was a consistent next step of the already implied monolatry, but now implicit became explicit, and the monolatric tendencies became intolerant. For the nomists Israel would only be allowed to worship one divinity, YнwH, while all others must be rejected. This idea is crystallized in the first commandment of the Decalogue: "You shall have no other gods before me," (Deut 5:7), and it is met in numerous different forms in commandments (e.g., Deut 12:2; 17:2-7), threats (e.g., Deut 29:21-27), and condemnations (e.g., 2 Kings 21:2-15). In many passages the danger posed by other gods is closely connected with cult items, objects, and religious phenomena that the nomists regard as illegitimate and foreign to their conception of pure Yahwism. ${ }^{33}$ One receives the impression that the nomists have gradually limited the acceptable form of Yahwism to a form that strips it of as many aspects as possible that are shared with other religions and especially those practiced in Palestine. Exclusivity and oneness eventually become central features of nomistic Yahwism, although they were probably meant as a means to an end and not the end itself.

Although the texts do not specify the concrete reasons for the intolerance and exclusivity, the perceived external and/or internal threat would provide an

32 A central feature of the nomistic texts is the repeated reference to the Law that the Israelites should obey. It is often difficult to distinguish between different nomistic texts, and they are probable a group of successive editors with similar ideological conceptions.

33 Among many other similar examples, Deut 7:5 lists foreign altars, stone pillars/Massebot, the Asherahs, and idols as representatives of illegitimate cults of the foreign gods and foreign nations. 
explanation. A group that feels its social identity threatened is more prone to attack and criticize other groups, especially those that are perceived to weaken the boundary between the ingroup and outgroup. ${ }^{34}$ With significant institutions of Yahwism destroyed in 587 BCE, Yahwism would have been at a constant risk of losing its uniqueness and identity, and one strategy to survive would have been a protective attitude towards everything that may threaten the only fragments of individuality that were left. These would have been emphasized and perhaps expanded, whereas features that threatened to weaken the boundaries between Yahwism and other religions would have been diminished or prohibited. This would explain why the Canaanites and other native people of the land are the main target of religious polemic in the narrative fiction of Deuteronomistic texts. The Mesopotamian or Egyptian religions are not perceived threats but those religions that are much closer to Yahwism. In effect, the nomistic criticism is targeted at the religion that lies at the background of Israel's own religious conceptions.

That the development of exclusive Yahwism is closely connected with identity and its protection is seen in its profound relationship with nationalistic tendencies. YHwH is the God of Israel and of Israel only (e.g., Deut 4:19; Deut 7; 29:25), while other nations have their own gods. Israel is described as Yнwh's

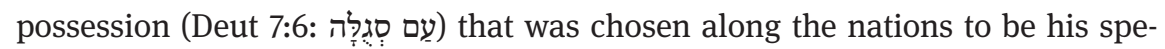
cial people (Deut 10:5). Israel will inherit the land if the Israelites follow his commandments (Deut 8; 9:1-6), the most important of which is the exclusive worship of YHwH. In the nomistic conception Israel's wellbeing as well as its relationship with YHWH is largely dependent on undivided loyalty towards YHwH as its God.

Although the idea of a law defining Yahwism is present already in earlier Deuteronomism, it becomes a prominent feature in the nomistic texts. The Law effectively replaced the temple as the main means to follow YHWH. Instead of sacrifices, the Israelites should approach Yнwн by obeying his law. The transformation of Yahwism from preexilic conceptions to Deuteronomistic and nomistic conceptions is illustrated in this chart: ${ }^{35}$

34 As noted by J. N. Shelton et al., "Threatened Identities and Interethnic Interactions," European Review of Social Psychology 17 (2006), 321-358, here p. 353: "perceived threats to identity are a primary source for intergroup tension, prejudice, and hostility." For terminology of ingroup and outgroup, see, for example, H. Tajfel et al., "Social Categorization and Intergroup Behaviour,” European Journal of Social Psychology, Vol. 1, Issue 2 (1971), 149-178.

35 For details and discussion, see J. Pakkala "The Nomistic Roots of Judaism," Houses Full of All Good Things. Essays in Memory of Timo Veijola (ed. J. Pakkala and M. Nissinen; PFES 95; Helsinki and Göttingen 2008), 251-268. 


\begin{tabular}{llll}
\hline & Preexilic religion & History Writer & Nomistic religion \\
\hline Core & Temple & Temple & Law \\
Mediator & King & King & Moses \\
Worship of YHWH & Sacrifices & Sacrifices & Obedience to the Law \\
Physical Symbol & YHwh's statue & & Tablets of the Law \\
\hline
\end{tabular}

The exclusive relationship between Israel and YHwH was further inspired by vassal and/or succession treaties. Although many of the same elements were already present in earlier nomistic texts, later nomistic editors were strongly influenced by the ideology and conceptions of vassal treaties. The relationship between the lord and the vassal was defined and specified in the terms of a treaty that was made between the counterparts. In most cases, the exclusive devotion of the vassal towards the lord was the rationale and goal of the treaty, and the various stipulations and terms aimed at keeping the vassal from following other lords. ${ }^{36}$ If the vassal was loyal the lord promised to protect the vassal from its enemies. This scheme was largely adopted mutatis mutandis in late nomistic texts: YHwH represented the lord, Israel the vassal, and Deuteronomy the treaty. The influence of the vassal treaties is most clear in Deut 13 and 28, both of which may have be literarily dependent on a vassal treaty, ${ }^{37}$ but the ideas can be found in many other late nomistic passages as well. ${ }^{38}$

The Deuteronomists and nomists did not represent the entire society. We are mainly dealing with a small group of people, whose ideas were adopted by all Jewish communities only slowly, perhaps only after centuries. It is thus probable that the worship of other divinities continued in many Yahwistic contexts much after these texts were written. For example, it is unlikely that Asherah would have been abandoned in all contexts immediately after 587 BCE. For everyone her cult was not dependent on the temple in Jerusalem. Since her cult is so ve-

36 The main rationale of succession treaties was to guarantee the safe transfer of power within the dynasty; the vassal was expected to assist and contribute to this by hindering any potential threats.

37 For a detailed discussion of these passages in relation to vassal treaties, see C. Koch, Vertrag, Treueid und Bund (BZAW 383; Berlin and New York 2008). He has shown that both chapters derive from a post-587 BCE context. Koch also excludes the possibility-argued by H. U. Steymans, Deuteronomium 28 und die adê zur Thronfolgeregelung Asarhaddons. Segen und Fluch im Alten Ound in Israel (OBO 145; Fribourg 1995) - that the Succession Treaty of Esarhaddon could be used to date Deuteronomy or these chapters.

38 For example, T. Veijola, Das fünfte Buch Mose (Deuteronomium) Kapitel 1,1-16,17 (ATD 8/1; Göttingen 2004), has found the same author's hand in many parts of Deuteronomy, especially in chapters 4 and $7-11,29-30$. 
hemently condemned much later (Deut 16:21; 2 Kgs 23:6), it seems probable that her cult was rather wide-spread and continued at least on a local level. The Elephantine letters also show that other gods were worshipped alongside with YHWH in some Yahwistic contexts still in the fifth century BCE. Although the Elephantine context may not be the best representation of Yahwism in the Persian period, the community was in contact with Jerusalem (including the high priest) and Samaria, which shows that it was not merely a secluded and abnormal Jewish community. Yahwism of the Persian period was practiced in various contexts in different parts of the Near East and it is probable that it took many local forms.

\section{Monotheistic Tendencies in Late Deuteronomistic Texts}

Some of the youngest Deuteronomistic texts show a further development of Yahwism. Instead of a hostile attack on the other gods, there is a group of six texts that deny their existence: Deut 4:32-40; Deut 7:7-11; 2 Sam 7:22-29; 1 Kgs 8:54-61; 1 Kgs 18:21-40 and 2 Kgs 19:15-19. Although they may not derive from the same author, many scholars have shown that they are some of the latest additions to the books in question. ${ }^{39}$

It is clear that the conceptions in these texts are far from systematic monotheism. Without any arguments or discussion about its basis, the passages bluntly claim that there is only one God, Yнwн, and all six passages share a core sentence that makes the claim: יהוה הוא האלהים (Yhwh is the God) or אתה הוא האלהים (You are the God)..$^{40}$ By adding אין עוד, Deut 4:35, 39; 1 Kgs 8:60 and 2 Kgs 19:15, 19 יהוה הוא : further specify that the phrase refers to the uniqueness of YHWH as God האלהים אין עוד.

Besides taking a step towards monotheism, these texts largely build on earlier nomistic conceptions. The nationalistic tendency is evident in Deut 4:32-40, 7:7-11 and 2 Sam 7:22-29, which is not entirely consistent if there are no other gods for other nations to worship. They refer to Israel's election from all the nations to be YHwH's own people. Israel's history is also used as proof that YHWH is the only God. Only 2 Kgs 19:15-19 is more open to the possibility that YHWH could be the God of all nations (cf. v. 15: לכל ממלכות הארץ), and it is possible that the author of 2 Kgs 19:15-19 was familiar with the monotheism of Deutero-

39 For discussion of the passages in question, see J. Pakkala, "The Monotheism of the Deuteronomistic History,” SJOT 21/2 (2007), 159-178.

40 The first person address is due to the context. 
Isaiah. ${ }^{41}$ The passages also contain some other elements that could be connected with monotheistic ideas: For example, Deut 4:32 and 2 Kgs 19:15 directly refer to creation, which is a development in comparison with conventional Deuteronomistic conceptions.

\section{Conclusions}

We may observe an evolutionary development in the Deuteronomistic texts. At the background are theological conceptions common in the Levant during the monarchic period, but there is a slightly elevated tendency towards monolatry at least in Judah by the seventh century BCE. The idea of an early form of Yahwism that differed fundamentally from other religions of the Levant should be rejected. After the destruction of 587 BCE the religion of Israel began a new trajectory that eventually led to monotheistic conceptions and developed into Judaism. An exceptional drive for oneness and the demand for exclusivity separated Yahwism from other religions of the Ancient Near East, but there is no evidence that these features emerged during the monarchic period. Rather than assume the historicity of Josiah's reform, the destructions of 587 BCE provide a more logical background for the revolutionary conceptions to emerge. A literary and redaction critical approach of Deuteronomistic literature shows that crucial stages in the emergence of oneness and exclusivity took place when the Deuteronomistic texts were written and edited from the sixth century BCE onwards. One can observe the development of monolatric features from the earliest Deuteronomistic texts to monotheistic conceptions in latest Deuteronomistic additions.

41 This aspect is much more developed in the monotheism of Deutero-Isaiah (see, for example, Isa 45,18-23). 
